\title{
THE CASE FOR DISTRICT COURT MANAGEMENT OF THE REAPPORTIONMENT PROCESS
}

\section{Supreme Court Guidelines}

Three judge district courts sitting in reapportionment cases have been put to the task of fashioning complex equitable remedies to insure that state governments will be "representative" 1 in the literal sense required by the equal protection clause. That the district courts have had difficulty in implementing this constitutional mandate is attributable not only to the inherent complexities of reapportionment, but also to the courts' failure to explore the nature of their remedial powers. This latter deficiency may be traced both to a similar lack of exploration by the Supreme Court and to the unwillingness of that tribunal to give more than marginal guidance on the question of the proper remedial devices available to the district courts. $^{2}$ In Reynolds $v$. Sims ${ }^{3}$ the Court said that if malapportionment is found, it would be "unusual" for a court not to take "appropriate action to insure that no further elections are conducted under the invalidated plan," although the imminence of an election might justify the delay of effective relief. ${ }^{4}$ As to the allocation of primary responsibility for the formulation of an apportionment plan, the Court said: "[L] egislative reapportionment is primarily a matter for legislative consideration and determination, and . . judicial relief becomes appropriate only when a legislature fails to reapportion according to federal constitutional requisites in a timely fashion after having had an adequate opportunity to do so." 5 As to the timing of relief, the Court said:

1 The constitutional requirement is that substantially equal quantums of people be represented by equal quantums of legislators. Reynolds v. Sims, 377 U.S. 533, 560-61 (1964); see Holt v. Richardson, 238 F. Supp. 468, 240 F. Supp. 724 (D. Hawaii), revieze granted sib nom. Burns v. Richardson, 34 U.S.L. WEEK 3101 (U.S. Oct. 12, 1965) (Nos. 318, 323) ; Ellis v. Mayor, 234 F. Supp. 945 (D. Md. 1964).

2 From the threshold reapportionment decision in Baker v. Carr, 369 U.S. 186 (1962), the Supreme Court refused to articulate precisely what remedial powers resided in the federal courts, and simultaneously denied that the courts were entering the political arena. Id. at 198, 226. This latter assertion was inaccurate both because of the necessity for the district courts to coddle legislators and because the area is rampant with partisan spoils. While the decisions in Gray v. Sanders, 372 U.S. 368 (1963), and Wesbury v. Sanders, 376 U.S. 1 (1963), clearly reinforced jurists' assumptions regarding what the Court's decision would be on the issue of equal representation in state legislatures, and thereby induced the district courts to announce the right and implement a remedy in advance of a firm decision by the Supreme Court, see Butterworth v. Dempsey, 229 F. Supp. 754, 773-74 (D. Conn.) (appended opinion of Clark, $J$., then deceased), aff'd per curiam sub nom. Pinney v. Butterworth 378 U.S. 564 (1964), it left the district courts with little more than aphorisms to guide the remedial process.

3377 U.S. 533 (1964).

4 Id. at 585 .

5 Id. at 586 . 
In awarding or withholding immediate relief, a court is entitled to and should consider the proximity of a forthcoming election and the mechanics and complexities of state election laws, and should act and rely on general equitable principles. With respect to the timing of relief, a court can reasonably endeavor to avoid a disruption of the election process which might result from requiring precipitate changes that could make unreasonable or embarrassing demands on a state in adjusting to the requirements of a court's decree. ${ }^{6}$

While the Court's tack is consistent with traditional equity analysis ${ }^{7}$ at first glance, its conservative approach to the remedial process is inconsistent with the practical implications of the reapportionment cases on the merits. For example, while reapportionment may ordinarily be a matter for "legislative consideration," it is not clear that it is a matter for consideration by a legislature which by force of the finding of malapportionment is "unrepresentative." 8 Furthermore, apart from the abstract problem of whether the finding of malapportionment in effect invalidates the present legislature, there is a serious problem of a conflict of interests when a legislator is asked to undermine the security of his seat. This conflict suggests that reapportionment cannot safely be allotted to the present legislators. ${ }^{9}$ And while the Supreme Court placed a high value on minimum disruption of state governmental processes, it did not visualize that reluctant interference by federal courts would result in lengthy, frustrating, and at least equally disruptive experiences in the process of reapportioning the state legislatures. ${ }^{10}$

\section{The Remedial Pattern in the District Court}

Despite these problems district courts, drawing from each other's experience have adopted a generally consistent course of action. Typically, a district court will first enjoin the holding of elections under the invalidated plan; ${ }^{11}$ if the election is imminent, however, the court will often abstain from action or delay the effective date of its order until after the

\section{${ }^{6} I d$. at 585.}

7 The approach outlined is strikingly similar to that in Brown v. Board of Educ., 349 U.S. 294, 300-01 (1954); cf. 113 U. PA. L. REv. 587, 602 (1965).

8 See text accompanying notes $39-44$ infra.

9 See text accompanying notes 66-73 infra.

10 See, e.g., 54 Nat'L CIVIC REv. 320 (1965). As might be expected, numerous legislative programs were neglected while the state legislators were preoccupied with reapportionment. See Toombs v. Fortson, 241 F. Supp. 65, 71 (N.D. Ga. 1965) (per curiam).

11 See, e.g., Ellis v. Mayor, 234 F. Supp. 945, 959 (D. Md. 1964) (municipal elections); Butterworth v. Dempsey, 229 F. Supp. 754, 790 (D. Conn.) (appended opinion of Clark, J, then deceased), aff'd and remanded per curiam sub nom. Pinney v. Butterworth, 378 U.S. 564 (1964). 
election. ${ }^{12}$ Positive judicial relief, on the other hand, has never been granted on the first challenge to the apportionment scheme. Without exception the courts have deferred to the legislature for at least one session, either with a profound expression of confidence that the legislature will take prompt action, ${ }^{13}$ or less confidently on the simple assertion that apportionment is primarily a legislative responsibility. ${ }^{14}$ In pursuing such a course of action, the court will sometimes make an attempt to spell out the requirements of equal protection as they apply to the particular state. ${ }^{15}$ In addition, the court's order occasionally appears to take the form of a mandatory injunction directed toward either the legislature ${ }^{18}$ or toward an administrative body charged with the duty of formulating election laws. ${ }^{17}$

A more demanding court may couple this initial deference with a deadline ${ }^{18}$ for legislative action and a warning that legislative default will result either in apportionment under a court made plan ${ }^{19}$ or in an election at large. ${ }^{20}$ More often these threats will be reserved for the court's second exhortation to the legislature, after the latter has failed to act. ${ }^{21}$ If the

12 See, e.g., Davis v. Cameron, 238 F. Supp. 462 (S.D. Iowa 1965) ; Stout v. Hendricks, 228 F. Supp. 568, 570 (S.D. Ind. 1964). But see Butterworth v. Dempsey, 237 F. Supp. 302 (D. Conn. 1965) ; Reynolds v. State Election Bd., 233 F. Supp. 323 (W.D. Okla. 1964) (per curiam); Lucas v. Forty Fourth Gen. Assembly, 232 F. Supp. 797, 799 (D. Colo. 1964), aff'd per curiam, 379 U.S. 693 (1965).

13 See, e.g., Davis v. Cameron, supra note 12, at 466; Honsey v. Donovan, 236 F. Supp. 8, 21 (D. Minn. 1964).

14 See, e.g., Petuskey v. Clyde, 234 F. Supp. 960, 964 (D. Utah 1964).

15 See, e.g., Butterworth v. Dempsey, 229 F. Supp. 754, 766 (D. Conn.) (appended opinion of Clark, J., then deceased), aff'd per curian sub nom. Pinney v. Butterworth, 378 U.S. 564 (1964). But see Petuskey v. Clyde, supra note 14, where the court refrained from particularizing to avoid advocacy of its suggestions as "court approved" or criticism as "court dictated."

16 See, e.g., Silver v. Jordan, 241 F. Supp. 576, 586 (S.D. Cal. 1964), aff'd per curiam, 381 U.S. 415 (1965). Although the language may seem to be that of a mandatory injunction, no court has ever suggested the availability of a contempt sanction upon noncompliance. Such a sanction would be entirely inappropriate, for a court clearly could not order a legislator to vote for any one of many possible plans, much less enforce agreement sufficient for a majority. See Friedelbaum, Baker v. Carr: The New Doctrine of Judicial Intervention and Its Implications for American Federalism, 29 U. CHr. L. REv. 673, 699-702 (1962) ; McKay, Political Thickets and Crazy Quilts: Reapportionment and Equal Protection, 61 MICH. L. REv. 645, 700-05 (1963) ; Note, 15 RutGERS L. REv. 82, 90-96 (1960). The actual sanction is that the defaulting legislature may be denied a role in reapportioning the state. See note 26 infra.

17 See, e.g., Yancey v. Faubus, 238 F. Supp. 290 (E.D. Ark. 1965) ; Reynolds v. State Election Bd., 233 F. Supp. 323 (W.D. Okla. 1964) (per curiam).

18 See, e.g., Mann v. Davis, 238 F. Supp. 458 (E.D. Va. 1964), aff'd per curiam sub nom. Hughes v. WMCA, Inc., 379 U.S. 694 (1965); Buckley v. Hoff, 234 F. Supp. 191 (D. Vt. 1964), aff'd per curiam with modification of deadline sub nom. Parsons v. Buckley, 379 U.S. 359 (1965).

19 See, e.g., Silver v. Jordan, 241 F. Supp. 576, 586 (S.D. Cal. 1964), aff'd per curiam, 381 U.S. 415 (1965); Schaefer v. Thomson, 240 F. Supp. 247 (D. Wyo. 1964); Drew v. Scranton, 229 F. Supp. 310, 328 (M.D. Pa. 1963), vacated and remanded per curiam, 379 U.S. 40 (1964) ; Moss v. Burkhart, 207 F. Supp. 885, 899 (D. Okla. 1962).

${ }^{20}$ See, e.g., Germano v. Kerner, 241 F. Supp. 715 (N.D. Ill.), vacated and remanded per curian sub nom. Scott v. Germano, 381 U.S. 407 (1965).

21 See, e.g., Thigpen v. Meyers, 231 F. Supp. 938 (W.D. Wash.), aff'd and remanded per curian, 378 U.S. 554 (1964); Sincock v. Duffy, 215 F. Supp. 169 (D. Del. 1963), aff'd and remanded sub nom. Roman v. Sincock, 377 U.S. 695 (1964). 
threat of judicial reapportionment has been invoked, the court may appoint a special master ${ }^{22}$ or may request suggestions from the litigants ${ }^{23}$ to prepare for such an eventuality. Conjointly-or alternatively-the court may declare that the legislature is now impotent to transact any business other than apportionment, at least until a constitutional reapportionment plan has been enacted. ${ }^{24}$ In all cases, the court will expressly retain jurisdiction until the remedy has been effected. ${ }^{25}$ Finally, repeated failure by the legislature to enact a constitutional plan may result in apportionment under a plan formulated or approved by the court. ${ }^{26}$

Although a court will often postpone relief in the shadow of an imminent election, ${ }^{27}$ it may choose not to permit the successful candidates to serve out their full terms of office ${ }^{28}$ and may order an election in what would ordinarily be an off year. ${ }^{29}$ One court has halved the terms of office of elected state senators, and it did so without giving warning of the possibility of such action at the time the election was held. ${ }^{30}$ Another court has employed precisely the opposite technique by enjoining the forthcoming election and continuing the sitting legislature in office beyond its official term. ${ }^{31}$

Throughout this process, the district court may be faced with provisions of the state constitution that will complicate, if not impede, the remedial process. In devising a remedy, one court has ignored timing provisions in the state constitution which would have delayed the imple-

22 See, e.g., Butterworth v. Dempsey, 237 F. Supp. 302 (D. Conn. 1965).

23 See, e.g., Drew v. Scranton, 229 F. Supp. 310, 328 (M.D. Pa.), vacated and remanded per curiain, 379 U.S. 40 (1964).

24 See, e.g., Holt v. Richardson, 238 F. Supp. 468, 240 F. Supp. 724 (D. Hawaii 1965), revieze granted, 34 U.S.L. WEEK 3101 (U.S. Oct. 12, 1965) (Nos. 318, 323); Mann v. Davis, 238 F. Supp. 458 (E.D. Va. 1964), aff'd per curiam sub nom. Hughes v. WMCA, Inc., 379 U.S. 694 (1965).

20 See, e.g., Stout v. Hendricks, 235 F. Supp. 556, 558 (S.D. Ind. 1964).

26 In Sims v. Frink, 208 F. Supp. 431 (M.D. Ala. 1962), the district court ordered into effect a provisional reapportionment plan which it had sewn together from parts of a stand-by reapportionment act and an invalid constitutional amendment. The Supreme Court found this, inter alia, a "well-considered exercise of judicial power." Reynolds v. Sims, 377 U.S. 533, 587 (1964). A reapportionment plan effective until the next census (barring a valid reapportionment by the legislature) was implemented by the Oklahoma district court in Moss v. Burkhart, 220 F. Supp. 149 (W.D. Okla. 1963), and the Supreme Court affirmed per curiam, although it did not expressly approve the action. Williams v. Moss, 378 U.S. 558 (1964). In Herweg v. Thirty Ninth Legislative Assembly, 246 F. Supp. 454 (D. Mont. 1965), the court formulated and ordered into effect an apportionment plan for the 1966 elections. In Paulson v. Meier, 246 F. Supp. 36 (D.N.D. 1965), a plan prepared by a C.P.A. hired by the Legislative Research Committee was modified by the court and declared to be the apportionment law of the state.

27 See, e.g., Stout v. Hendricks, 228 F. Supp. 568 (S.D. Ind. 1964). This complies with the Reynolds suggestions. 377 U.S. at 585.

28 The New York district court entered a decree on July 27, 1964 permitting the November 1964 elections to be held under the invalidated apportionment plan, but limited the terms of the legislature to one rather than two years. The Supreme Court affirmed. Hughes v. WMCA, Inc., 379 U.S. 694 (1965) (per curiam).

20 Tombs v. Fortson, 241 F. Supp. 65 (N.D. Ga. 1965) (per curiam).

30 Mann v. Davis, 238 F. Supp. 458 (E.D. Va. 1964), aff'd per curiam sub nom. Hughes v. WMCA, Inc., 379 U.S. 694 (1965).

31 Butterworth v. Dempsey, 237 F. Supp. 302 (D. Conn. 1965). 
mentation of a remedy. ${ }^{32}$ In yet another case the court told the state legislature that in devising a plan it could ignore certain provisions of its state constitution relating to the size of one of the legislative houses, and that if the court were forced to reapportion the state, it too would ignore those provisions. ${ }^{33}$

\section{Judicial Power as a Function of Legislative Illegitimacy}

The nature of the remedial powers possessed by the district courts in the reapportionment sphere turns largely on the effect on the state legislature of an invalidation of the state districting system. If such action does not deprive the legislature of the intrinsic right to act for the people of the state, district court power is merely corrective and secondary. Judicial relief is therefore available only if the legislature defaults. ${ }^{34}$ While the uniform response of the district courts in withholding affirmative relief until the sitting legislature has had an opportunity to act suggests that the courts are recognizing the power of these legislatures to pass valid laws, certain other dispositions indicate that the judicial attitude toward the legitimacy of such legislatures is, at the minimum, an ambivalent one. For example, when a court curtails the terms of office of the incumbent state legislators and orders an early election, ${ }^{35}$ the implication is that the legislature is not legally entitled to sit. Similarly, the act of enjoining a legislature from transacting any business except that relating to the formulation of new apportionment plans ${ }^{36}$ challenges the authority of that legislature in two apparent ways. Such a decree effectively strips the legislature for an uncertain length of time of its plenary powers to legislate for the state and confines it to an area expressly excepted by judicial decree. In addition, this type of approach approximates federal control of the state legislative agenda-a matter ordinarily thought to be so internal that federal judicial interference is inconsistent with the idea that the affected legislature is a legitimate branch of government. Viewed in this light, the repeated assumptions by the district courts that a finding of malapportionment does not undermine the legitimacy of the present legislature ${ }^{37}$ may be viewed

32 Buckley v. Hoff, 234 F. Supp. 191 (D. Vt. 1964), aff'd per curiam with modification of deadline sub nom. Parsons v. Buckley, 379 U.S. 354 (1965) ; see Petuskey v. Rampton, 243 F. Supp. 365 (D. Utah 1965).

33 Schaefer v. Thomson, 240 F. Supp. 247 (D. Wyo. 1964). Despite the court's facilitation of the process, the legislature failed to come forward with a reapportionment plan. 54 NAT'L CIVIC REv. 206 (1965). supra.

34 This conforms to the Supreme Court's view. See text accompanying note 5

35 See notes 28-30 supra and accompanying text.

36 See text accompanying note 24 supra. In Petuskey v. Rampton, 243 F. Supp. $365,373-74$ (D. Utah 1965), the district court prohibited the legislature from considering or voting upon any proposal to amend the Constitution of the United States on the subject of legislative reapportionment and from taking any action on that subject except to stagger the terms of senators.

37 See Germano v. Kerner, 241 F. Supp. 715, 718 (N.D. I11.), vacated and remanded per curiam sub nom. Scott v. Germano, 381 U.S. 407 (1965). The source of the assumption is the Supreme Court's view that the legislature be given the first 
merely as attempts to cut short the logical but anomalous conclusion that such a finding destroys the authority of a governmental unit. If this latter estimate of the legislatures' legal status is correct, it will no longer be possible to speak in traditional terms about judicial infringement upon the sphere of the legislature, for vis-à-vis the court there is no legislature sitting under the authority of law.

In cases where the decision invalidating the system of apportionment occurs before the election of the legislature, and the court allows the election to proceed only because of an equitable judgment that the withholding of relief will minimize disorder of state government, it is clearly appropriate to characterize the authority of the legislature as existing by grace of the district court. The problem is more difficult where the invalidating decision postdates the election of the legislature. In such a case, it may be argued that the sitting legislature is a legitimate one because the representatives were duly elected under state law, and it is purely a state function to decide who constitutes its legislative bodies. A conjunctive argument is that the decisions in the reapportionment cases went narrowly to the impropriety of the method of election, and that whatever wrong resulted (the dilution of the vote) occurred at the time of the election. It would then follow that the invalidating effect of the reapportionment decisions is applicable to the method of holding elections in the future, but not to the authority of the present legislature.

These arguments are not sound. To begin with, where the state constitution required that apportionment be according to population, the legislature of a malapportioned state was not only improperly chosen under the federal constitution, but was also never elected according to state law..$^{38}$ Even in the absence of such a provision in the state constitution, the illegitimacy of the sitting legislature, at least to the extent that it can pass valid legislation, flows directly from the right to an undiluted vote. The

opportunity to reapportion. Reynolds v. Sims, 377 U.S. 533, 586 (1964); Maryland Comm. for Fair Representation v. Tawes, 377 U.S. 656, 676 (1964). All district courts have initially deferred. See Note, 1965 DUKE L.J. 563, 572 n.48. In Stout v. Hendricks, 228 F. Supp. 568, 571 (S.D. Ind. 1964), the court implied that the legislature was not rendered illegitimate unless the court specifically voided the election, but that the court had the power to do so, although to exercise the power would be "reckless." Other courts view the legislature's power as derived from its "de facto" status, though the same courts seem compelled to grant this status expressly. League of Nebraska Municipalities v. Marsh, 232 F. Supp. 411, 414 (D. Neb. 1964); see Jonas v. Hearnes, 236 F. Supp. 699, 708 (W.D. Mo. 1964); Paulson v. Meier, 232 F. Supp. 183, 190 (D.N.D. 1964). But see id. at 191 (Davies, J., dissenting). This concept is developed in text accompanying notes 48-49 infra. The power of the legislature may be viewed as conditional upon compliance with the court's decrees. See Butterworth v. Dempsey, 237 F. Supp. 302, 308 (D. Conn. 1965), which implies that it exists by the grace of the court. Cf. Jackman v. Bodine, 43 N.J. 453, 473, 205 A.2d 713, 724 (1964): "The answer is provided abruptly by sheer necessity." Necessity may require that a legislature be present to handle daily tasks and prevent a dangerous interregnum, but this does not mean that the legislature has an intrinsic claim to legitimacy based upon its commission. Furthermore, even if preserving a legislative power is necessary for these purposes, it does not answer the controlling question of whether its power should extend to the shaping of future legislatures by controlling reapportionment.

38 Cf. Baker v. Carr, 369 U.S. 186 (1962). 
concept of one undiluted vote for each qualified voter has little significance in its own right; ${ }^{39}$ it is an intermediate step to the end that the representatives of a majority of the people shall constitute a majority of the legislature. The immediate wrong sought to be remedied is the passage of legislation by a majority of representatives who represent a minority of the people.40 The wrong is not limited, however, to the enactment of minority legislation, but extends also to the absence of legislation which might be enacted, were the representatives of the majority presently sitting. ${ }^{41}$ Thus it is inconsistent on one hand to declare a right to an undiluted vote and on the other to declare that the legislature sitting under a malapportioned scheme is legitimate, at least to the extent that it has an inherent right to legislate for the state. It is also clear that the impact of malapportionment is quotidian: every day that a legislature elected under an invalidated system is allowed to sit results in the perpetuation of the wrong for which a remedy is sought. ${ }^{42}$ Thus, a ruling that equal representation quantums must be allocated to equal population quantums logically requires that the present legislature be rendered powerless to act and that its legitimate successor take office with all possible speed. ${ }^{43}$ Under this reasoning, if the legislature remains in power after malapportionment has been found, its tenure is not attributable to its right to hold office, but can be traced instead to an equitable judgment of the court that it should be permitted to retain its power. ${ }^{44}$

39 The ease of compartmentalizing the concepts of legislative legitimacy and the right to an undiluted vote undoubtedly flows from the Supreme Court's approach to reapportionment as the vindication of the rights of the individual voter, Reynolds v. Sims, 377 U.S. 533, 568 (1964), leaving only as an inference the possibility that the status of the legislature has been adversely affected. Compare Dixon, Reapportionment in the Supreme Court and Congress: Constitutional Struggle for Fair Representation, 63 MiCE. L. REv. 209, 218 (1964), with Kauper, Some Comments on the Reapportionment Cases, 63 MICH. L. Rev. 243, 244 (1964).

40 See Schubert, Reapportionment 2 (1965) ; cf. Hacker, Congresstonat ReDISTRICTING 71-91 (1963).

41 Jewell, Political Patterns in Apportionment, in The Poltrics of ReAprortionMENT 1, 18-19 (Jewell ed. 1962).

42 To some extent the textual statement is applicable to all legal wrongs. The difference in the reapportionment area, though of degree, is substantial because unconstitutional imperfections in the legislature affecting any policy course it may or may not pursue potentially affect the day by day activities of every person within the state. Nor does it matter that the legislature may be in session for only a few months of each year, for the interim months are presumably used by the legisiators to conduct at least limited colloquy with some of their constituents, to formulate new legislation, to resolve stands on proposed legislation, and to align support. It is this pervasive and quotidian effect of malapportionment together with the fact that reapportionment seeks primarily to correct stateways, not folkways, that accounts for the much shorter time requirements imposed by the courts in the reapportionment area as compared with the ten year "all deliberate speed" requirement of the desegregation decisions.

See MCKAy, ReAprortionment 218 (1965). But see Dixon, supra note 39, at 229.

43 "Permitting elections . . . as now scheduled, means two more years of obvious unequal representation, two more years of taxation with partial representation, and two more years of a delayed remedy which I cannot in good conscience justify." Paulson v. Meier, 232 F. Supp. 183, 192 (D.N.D. 1964) (Davies, J., dissenting). The district court ultimately had to apportion the state by decree. 246 F. Supp. 36
(D.N.D. 1965).

44 See note 37 supra. 
Although this reasoning has never been articulated by the federal courts, the same conclusion was reached on more technical grounds in Kidd v. McCanless, ${ }^{45}$ a state case antedating Baker v. Carr. In Kidd the Tennessee Supreme Court explicitly based its refusal to invalidate an apportionment provision on the ground that such action would leave the state without a legislature. In so concluding, the court held that the de facto doctrine, which is used to sustain the validity of the acts of a governmental body subsequently found to be acting without authority, could not be employed to validate the future acts of that body. ${ }^{46}$ The conclusions reached by the Tennessee Supreme Court are particularly significant because the case preceded the federal reapportionment decisions. This meant that the court was not under pressure to find legislative legitimacy to avoid the governmental hiatus resulting from the declaration of a federal right entailing the invalidation of the election which was the legislature's claim to legal authority.

Because such pressure has been generated by the Supreme Court's reapportionment decisions, the federal district courts have repressed the conclusion that the sitting legislatures are illegitimate. In so doing, however, those courts have been unable to repress fully their concern that the status of the legislatures has been adversely affected.47 Evidence of this concern is found in statements that the legislature of a malapportioned state has "de facto" 48 authority to legislate and to pass a valid apportionment plan. These statements, which would appear technically incorrect in light of the Kidd analysis, ${ }^{49}$ indicate that the courts are, at the minimum, differentiating such legislatures from those sitting under the authority of

45292 S.W.2d 40 (Tenn. 1956).

$46 I d$. at 44 .

47 See, e.g., Stout v. Hendricks, 228 F. Supp. 568, 571 (S.D. Ind. 1965).

48 See, e.g., Jonas v. Hearnes, 236 F. Supp. 699, 708 (W.D. Mo. 1964) ; League of Nebraska Municipalities v. Marsh, 232 F. Supp. 411, 414 (D. Neb. 1964); Paulson v. Meier, 232 F. Supp. 183, 190 (D.N.D. 1964). But see id. at 191 (Davies, J., dissenting). It is instructive to note that when asked to explicate the practical content of the term "de facto," the same courts have demurred on grounds that the opinion would be advisory. See Jonas v. Hearnes, 246 F. Supp. 70 (W.D. Mo. 1965); Paulson v. Meier, 246 F. Supp. 36, 45 (D.N.D. 1965).

49 See also State ex rel. Martin v. Zimmerman, 249 Wis. 101, 23 N.W.2d 610 (1946). The limitation of the de facto doctrine is that it is effective to preserve from attack only those acts of a governmental office or agency occurring before the determination that the body is not duly constituted-i.e., when it was presumed to be de jure. The purpose of the doctrine is to preserve the past acts because of the reliance of both the public and the government upon them. When there has been a determination that the office or agency is invalid, there are no grounds for justified reliance and the continuity of governmental operations may be preserved by speedy legitimization of the body involved. Compare Note, 15 RuTGERS L. REv. 82, 88 (1960), where, in an effort to avoid the conclusion that the legislature is rendered impotent by a finding of malapportionment, it is argued that its illegitimacy goes only so far as the inability to pass legislation affecting the rights of individuals while the legislature may pass laws "regulating its own existence." Even if this distinction is granted, it is clear that to the extent that the complexion of the legislature determines the complexion of its enactments, reapportionment affects individual rights in the broadest sense possible. Indeed, the reapportionment decisions rest on the theory that individual rights are being vindicated. See Sims v. Baggett, 247 F. Supp. 96, 99 (M.D. Ala. 1965); note 39 supra. 
law. Similar implications arise when a court orders the state legislature to submit a plan for approval, ${ }^{50}$ for such a disposition treats the legislature more as an arm of the court than as an independent governmental body.

The thrust of the foregoing analysis is that the Supreme Court's holding that a district court acts properly in withholding relief until the legislature has had an opportunity to act, and that judicial relief becomes appropriate only when the legislature fails to act, cannot logically rest on constitutional interpretations of the limits of spheres of power. An equally viable interpretation of the propriety of delaying judicial interference is that it is based upon practical and "diplomatic" considerations: even if the sitting legislature is not lawfully ordained, it still is organized as a legislative body and presumably has the experience and facilities to explore the needs of a particular state and to formulate a reapportionment plan. The district court, on the other hand, may not have such facilities, and the convening of a three judge district court will in any event impede the economical use of judicial time within a circuit.51 In addition, the task of fashioning a reapportionment plan may monopolize the panel's time for a considerable period. Moreover, because of vociferous opposition by legislators to the role of the courts in this area, ${ }^{52}$ it may be judged that initial deference to the legislature performs an important assuaging function.

The controlling motivation for deference to the state legislatures, however, was probably to keep the federal courts from making decisions of immense potential partisan consequence, since such decisions could bring upon the courts great pressures and inevitable criticism from the state legislators and other partisan interests. The intensity of the feelings of the powers affected is evidenced by their vociferous opposition to the reapportionment decisions themselves regardless of whether the courts allowed the legislatures the first opportunity to reapportion. This reaction is understandable, for reapportionment necessarily threatens basic power structures built up upon existing representational units.

Such considerations should not be allowed to impair the integrity of the right and the effectiveness of the remedy. There are strong arguments that deference to the legislature permits this to occur. First, a sitting legislature has an interest in delaying the formulation of a reapportionment plan, for rapid formulation permits rapid implementation of the new system, while the present legislature has an occupational interest in retaining the

50 Germano v. Kerner, 241 F. Supp. 715 (N.D. Ill.), vacated and remanded per curiam sub nom. Scott v. Germano, 381 U.S. 407 (1965).

51 Drain on judicial manpower is one of the recurring focal points for criticism of the three judge district court mechanism. See Note, 72 Y ALE L.J. 1646 (1963).

52 See the picturesque account of a Georgia reapportionment session in Wesberry, "Non-People Factors," 54 NAT'L CIVIC REV. 188 (1965). The opposition to the reapportionment decisions came, quite revealingly, from the legislators involved, not the people they purportedly represented. See McKAY, REAPPoRTronMENT 218-21 (1965). It escalated into attempts to amend the Constitution to preclude judicial interference. See note 55 infra. 
existing plan. ${ }^{53}$ Prolonging the process on the gamble that the court will not apportion on its own initiative buys time for seats which may be endangered because their existence is tied to a malapportioned system. Second, a serious side effect of throwing the apportionment problem to a partisanly oriented body is the electric conflict which will be generated over the spoils of districting.54 The acrimony which results may be directed toward the courts in their role as the enforcers and articulators of the reapportionment requirements, and this in turn will damage the strength of judicial authority and encourage drives to remove federal court jurisdiction in this area.55 Finally, and most important, if the wrong of malapportionment is the disproportionate influence of the minority, judicial deference at this juncture merely provides an opportunity to memorialize the wrong in the form of a minority shaped reapportionment plan..$^{56}$

To understand the probable consequences of affording the legislature such an opportunity, it is necessary to have an elementary picture of some of the mechanics of reapportionment. For all practical purposes, reapportionment requires redistricting, ${ }^{57}$ because the configuration of the present districts rarely yields commensurable population quantums which would permit mere allocation of representatives. Theoretically, redistricting without regard to topography or traditional political subdivisions could produce districts with practically no population variances. Attention to such factors, however, has been declared to be permissible ${ }^{58}$ so long as "the overriding objective" is "substantial equality of population among the various districts," 59 and maximum population variances among the dis-

53 See, e.g., Petuskey v. Clyde, 234 F. Supp. 960, 964 n.6 (D. Utah 1964); cf. Petuskey v. Rampton, 243 F. Supp. 365 (D. Utah 1965) (legislature set up a satisfactory plan, but delayed putting it into operation).

54 See Boyd, Changing Patterns of Reapportionment 24-25 (National Municipal League Pamphlet 1965).

55 See generally Asch, A Revieze of Legislative Apportionment in Neze York State, 11 N.Y.L.F. 187, $192-98$ (1965); Black, The Proposed Amendment of Article $V: A$ Threatened Disaster, 72 Y YLE L.J. 957 (1963); McKay, Contr, Congress and Reapportionment, 63 MICE. L. Rev. 255 (1964); McKay, Don't Amend the Constitntion, 38 State Gov't 121 (1965).

56 "[T] he political remedy suggested is the very one which has caused the wrong." Moss v. Burkhart, 207 F. Supp. 885, 904 (W.D. Okla. 1962) (Rizley, J., dissenting).

67 Other methods, however, have been suggested. See, e.g., Germano v. Kerner, 241 F. Supp. 715 (N.D. I11.), vacated and remanded sub nom. Scott v. Germano, 381 U.S. 407 (1965) (election at large); Thigpen v. Meyers, 231 F. Supp. 938, 940-41 (W.D. Wash.), aff'd and remanded per curiam, 378 U.S. 554 (1964) (weighted voting). See generally Note, 1965 Duke L.J. 563, 582-88.

58 So long as the divergences from a strict population standard are based on legitimate considerations incident to the effectuation of a rational state policy, some deviations from the equal-population principle are constitutionally permissible. . . But neither history alone, nor economics or other sorts of group interest are permissible factors in attempting to justify disparities from population-based representation.

Reynolds v. Sims, 377 U.S. 533, 579-80 (1964).

69 Id. at 579. 
tricts in the ratio ${ }^{60}$ of 1 to 1.7 are at least "arguably" permissible. variances in population in a plan formulated by the legislature may not, however, be the products of permissible considerations. To illustrate, assume that a plan which respects the more significant natural and historical boundaries would have a maximum population variance ratio of 1.6 to 1 and that the state legislature passes a plan with a ratio of 1.5 to 1 . While this plan is "arguably" constitutional, it is not actually so if the variances are due to efforts to preserve "safe" seats for the present representatives or to reap partisan advantage rather than to those considerations which the Supreme Court has indicated are permissible grounds for variance. $^{62}$ Akin to this problem is the situation in which the reapportionment does not in itself increase the population variances, but is a clear gerrymander. ${ }^{63}$ The reapportionment decisions are, of course, not aimed at the evil of gerrymandering, and gerrymandering itself is not presently remediable in the federal courts, in the absence of a clear showing of resulting racial discrimination. ${ }^{64}$ Yet even if relief against the traditional

60 A population variance ratio indicates the ratio of the population contained in any two representational units. Thus, given two districts of population 100,000 and 75,000 , the population variance ratio is 1.33 to 1 . The term "maximum population variance ratio" means the ratio resulting from the comparison of the largest and smallest representational units in a single state's reapportionment plan.

61 Lucas v. Colorado Gen. Assembly, 377 U.S. 713, 727, 730 (1964).

62 League of Nebraska Municipalities v. Marsh, 242 F. Supp. 357 (D. Neb. 1965).

63 In Maryland the legislature formulated a plan for districts of substantial arithmetic equality with the purpose and effect of preserving the preexisting power structure, leaving the areas suffering from malapportionment in a politically weaker position. See Dixon, supra note 39, at 216. See also 54 NaT'L CIVIC Rev. 99 (1965).

"Gerrymandering" is used here in the broad sense of the process by which a dominant or incumbent political group chooses representational units for the purpose of preserving or enhancing its own political strength. It is clear that a definition which requires overt "animal cracker" districting by the dominant party is naively restrictive. See Hacker, Congressional Districting 46-47 (1963); Note 1965 DUKE L.J. $563,592$.

64 The Supreme Court has held that an allegation that city lines were redrawn to exclude Negro voters from municipal elections stated a cause of action. Gomillion v. Lightfoot, 364 U.S. 339 (1960). A challenge alleging the racial gerrymandering of congressional districts in New York failed for insufficient proof that the districting was intentionally discriminatory. Wright v. Rockefeller, 376 U.S. 52 (1962), affirming 211 F. Supp. 460 (S.D.N.Y. 1962); see The Supreme Court, 1963 Term, 78 Harv. L. REv. 252-54 (1964) ; Note, 72 Y ALE L.J. 1041, 1056-61 (1963). Similar problems of proof are presented where the allegation is of an improper dilution of votes through the use of multi-member or floterial districts. Mann v. Davis, 245 F. Supp. 241 (E.D. Va.), aff'd sub nom. Burnette v. Davis, 86 Sup. Ct. 181 (1965). But see Sims v. Baggett, 247 F. Supp. 96 (M.D. Ala. 1965), where the court distinguished the Wright case on the grounds that (1) in New York the nonwhites had long had actual sufferage, while in Alabama nonwhites had long been denied the vote, and that $(2)$ in New York, the district lines had long been erratic, while in Alabama the state had historically been districted by the use of single county units, while the plan before the court employed multi-county units which turned Negro majorities into Negro minorities. The court found that the evidence showed the effect of the plan, and inferentially the intent of the legislature, was to discriminate against Negroes, and the court invalidated the apportionment of the Alabama House of Representatives. Id. at 109-10. Yet the court thought that the more common nonracial political gerrymandering "may continue to present a 'political' question with which the judicial branch is not equipped to deal." Id. at 104. In Fortson v. Dorsey, 379 U.S. 433 (1965), reversing $228 \mathrm{~F}$. Supp. 259 (N.D. Ga. 1964), the Supreme Court had held that the use of multi-member districts was not alone violative of equal protection standards. But the Court added: "It might well be that, designedly or otherwise, a multi-member constituency appor- 
type of gerrymandering continues to be so limited, it may be that gerrymandering by an "unrepresentative" legislature is still not constitutionally permissible. The reasoning would be that to the extent that gerrymandering is permissible under the Constitution, it must at least be done by the representatives of the majority of the people. Otherwise, the present legislators are given an effective opportunity to perpetuate the same complexion in the legislature which was the result of malapportionment, and thereby can virtually emasculate the remedy. ${ }^{65}$

The danger that the legislature will impede effective implementation of the Supreme Court mandate is not a matter of conjecture, but is emphatically evidenced by previous reactions of state legislatures in these situations. ${ }^{66}$ To take one recent example, the legislature of New York was "constitutionally Republican" 67 for years, since the state apportionment plan all but insured Republican control. It is notable that when that plan was invalidated by the Supreme Court, ${ }^{68}$ the legislature predictably came forward with a proposal clearly gerrymandered to perpetuate Republican control. ${ }^{69}$

Even when one party does not possess sufficient strength in the sitting legislature to pass such a plan, there is usually an effort to preserve the status quo, ${ }^{70}$ thus strengthening the proposition that the greatest pro-

tionment scheme, under the circumstances of a particular case, would operate to minimize or cancel out the voting strength of racial or political elements of the voting population. When this is demonstrated it will be time enough to consider whether the system still passes constitutional muster." Id . at 439. (Emphasis added.) This statement may indicate that the Court will be willing to consider allegations of nonracial gerrymandering, although Burnette v. Davis, stipra, implies that the standards of proof in the Wright case have not been relaxed. See generally Note, The Apportionment Cases: An Expanded Concept of Equal Protection, 1965 WIS. L. REv. 606, 617-51.

65 This view provides a limited gerrymandering remedy which does not require that gerrymandering be a judicially cognizable wrong in other situations, but which recognizes that as a device to distort the weighting of votes, its prohibition is necessary to protect the reapportionment remedy. Put another way, a finding that apportionment was carried out with the intent and effect of preserving or increasing the present disproportion of power might violate the legislature's obligation to apportion honestly and in good faith. See Reynolds v. Sims, 377 U.S. 533, 577 (1964); Lucas v. Colorado Gen. Assembly, 377 Ü.S. 713, 735 (1964). There should be no hesitation, however, in providing a remedy for gerrymandering, for it is there that the greater evil lies: while malapportionment merely dilutes the weight of an individually cast vote vis-à-vis votes cast in other districts, gerrymandering completely eradicates the weight of the vote-it may as well have never been cast.

60 See Jewell, supra note 41, at 27-29.

67 Tyler \& Wells, "Constitutionally Republican," in THE Politics of ReapporTIONMENT 221-48 (Jewell ed. 1962).

68 WMCA, Inc. v. Lomenzo, 377 U.S. 633 (1964).

69 Reapportionment Compliance Act of 1964, N.Y. UNCoNsol. LAws $\$$ 2361-64, 2371-73, 2381-83, 2391-93 (McKinney Supp. 1965); see 54 NAT'L Crvic REv. 97-98 (1965).

70 See, e.g., Moss v. Burkhart, 220 F. Supp. 149, 154 (W.D. Okla. 1963), aff'd and remanded per curiam sub nom. Williams v. Moss, 378 U.S. 558 (1964): "[I]t is manifest that the legislative apportionment . . is a patchwork of political maneuvering and manipulation, to perpetuate the same invidious apportionment which prevailed under the antecedent laws." Holt v. Richardson, 240 F. Supp. 724, 731 (D. Hawaii), review granted sub nom. Burns v. Richardson, 34 U.S.L. WEEK 3101 (U.S. Oct. 12, 1965) (Nos. 318, 323): “[T]he legislature's adamant insistence on three and four-member senatorial districting was the conscious or unconscious-though not unnatural-reluctance of the affected senators to carve out single-member districts 
pensity to perpetuate the status quo lies with those who have the greatest stake in it. To the extent that the current complexion of the legislature is attributable to the invalidated apportionment scheme, and to the extent that efforts to preserve the same interests and faces are successful, the remedy is diluted by repressing the effects that would result from an accurate apportionment of the state according to population.

Where there has been a deviation from equality of population to preserve the status quo, the remedy has clearly been diluted and the plan cannot be allowed to stand. One notable example of an attempt to subvert the apportionment remedy occurred in the reapportionment of $\mathrm{Ne}$ braska. ${ }^{71}$ The federal court had initially deferred to the legislature of that state but was forced to invalidate the plan submitted by that body, even though the population variance ratio fell within the limits approved by the Supreme Court. ${ }^{72}$ The court's action was based upon a finding that "the districts have been created to facilitate keeping present members in office and, except in one district, to provide boundaries that will keep the present members from having to contest with each other at the polls." 73

Although the Nebraska district court was able to discern the damage to effective reapportionment that the legislative proposal would have inflicted, an equally perceptive court will not always be available. In reapportionment, every geometrical decision has political consequences, and political decisions will also affect the geometry of reapportionment. Furthermore, the decision to draw a line bounding one district may have immediate political consequences not only for that district, but also for the district or districts across the line-or possibly throughout the entire state, affecting the comparative population variance ratios. Because of the intricacy of both the process and the effects, it is difficult for a court on review to determine if and where impermissible variances have been made. Even if the court should successfully detect such variances, the legislative action will have seriously delayed the reapportionment process. These considerations suggest that the court should not defer initially to the state legislature to secure new apportionment of the state, but should itself assume responsibility for reapportionment from the start of the remedial process.

The preceding discussion emphasizes the crucial importance of properly allocating the initial responsibility for formulating a reapportionment plan. One reason for concern about who has the initiative has already been mentioned: review of disguised variances from equal population is very difficult. A second justification for this concern is that time is a

which thereafter would in all probability result in a political duel-to-the-death with a fellow and neighbor senator."

71 League of Nebraska Municipalities v. Marsh, 242 F. Supp. 357 (D. Neb. 1965).

72 See Lucas v. Colorado Gen. Assembly, 377 U.S. 713, 727, 730 (1964) (by implication) (maximum population variance ratio of 1.7 to 1 "arguably permissbile"). In the Nebraska case, supra note 71, the maximum population variance ratio of the submitted plan was 1.6 to 1. 242 F. Supp. at 359. Alternative plans considered by the court would have yielded ratios of 1.39 to 1 and 1.26 to 1 . Id. at 361 .

73 Ibid. 
decisive element of constitutional remedial demands ; ${ }^{74}$ consequently, any allocation of responsibility which will result in unnecessary delay is improper. Allocation of responsibility to the legislature invites delay not only because of a self interest therein, ${ }^{75}$ but also because of the probability of a succession of unacceptable apportionment plans. ${ }^{78}$ Finally, although the first reapportionment of a state may be said to fulfill its objective if it merely releases the stranglehold 77 of the present legislature so that the successor legislature may, if it so wishes, pass another reapportionment plan in due course, it is highly likely that even a temporary reapportionment plan will tend to perpetuate itself, at least until the next census, since the representatives elected thereunder will have reason to identify their occupational future with the permanence of the plan which permitted their election. The probability of such identification magnifies the importance of proper formulation of the initial plan.

In summary: Where the apportionment scheme of a state is declared unconstitutional, a court is confronted with a legislature which is not a legitimate decisional body, but which may be used by the court to aid in the performance of certain functions. Because reapportionment is inimical to the private interests of a great number of the incumbent representatives, however, entrusting the legislature with the responsibility for devising a new plan is likely to produce delay and self seeking districting which will prevent the consequences that would otherwise result from reapportionment. Thus, the state legislature should not be selected as the initial locus for the formulation of the reapportionment plan.

\section{Circumscription of District Court Power by State Constitutional Provisions}

Although a district court may be able to take the initiative in reapportioning a state, there are limitations on the content of the plan it can formulate. The invalidation of state apportionment provisions leaves much kindred law remaining on the books. A district court can, of course, render this residual law inoperative to the extent that it constitutes an integral or a dependent part of the unconstitutional apportionment scheme. ${ }^{78}$

74 See note 42 supra and accompanying text.

75 See Petuskey v. Rampton, 243 F. Supp. 365 (D. Utah 1965) (attributing delay in effecting reapportionment to desire of legislators to continue in office).

76 See, e.g., the Indiana litigation: Stout v. Hendricks, 228 F. Supp. 568 (S.D. Ind. 1963); Stout v. Hendricks, 235 F. Supp. 556 (S.D. Ind. 1964) ; Stout v. Bottorff, 246 F. Supp. 825 (S.D. Ind. 1965).

77 Cf. Baker v. Carr, 369 U.S. 186, 260 (1962) (concurring opinion) ; Butterworth v. Dempsey, 229 F. Supp. 754, 784 (D. Conn.), aff'd and remanded per cutriam sub nom. Pinney v. Butterworth, 378 U.S. 564 (1964).

78 See, e.g., Petuskey v. Clyde, 234 F. Supp. 960, 963 (D. Utah 1964) :

[I] $t$ is mathematically impossible to apportion upon a population basis a House of Representatives composed of not more than ninety members and with each county having at least one member. Thus, in application, the restrictive provisions of the Utah Constitution are in irreconcilable conflict with the Constitution of the United States and, being so, are themselves federally un- 
Much of this law, however, lies in a shadowy area only incidentally related to the invalidated apportionment provisions. Whether such law is a separable body of law which remains in force after the apportionment provisions are struck down would appear to be a question that the state courts should resolve. ${ }^{79}$ The boundaries of the proper exercise of federal judicial power in this area, however, are by no means clear, ${ }^{80}$ and the question to be explored is whether there are resonant effects of the supremacy clause which permit a district court to ignore and avoid apparently valid provisions of a state election scheme when formulating a remedy for malapportionment.

Where the provision in question would seriously postpone relief, the district court unquestionably has the power to disregard it. Such a situation was presented in Buckley v. Hoff, ${ }^{81}$ where the district court was confronted with a "time lock" provision of the Vermont Constitution prescribing a reapportionment every ten years. In Buckley any apportionment before 1970 would have been forbidden if the provision were operative, and

constitutional and must be considered as totally void in application under the supremacy clause of the Constitution of the United States. And we so hold. (Footnote omitted.) See Mann v. Davis, 213 F. Supp. 577 (E.D. Va. 1962), aff'd and remanded, 377 U.S. 678 (1964).

The invalidation of apportionment provisions contained in the state constitution leaves the legislature free to enact at least temporary apportionment legislation, although it would not ordinarily be empowered to do so. Maryland Comm. for Fair Representation v. Tawes, 377 U.S. 656, 675-76 (1964). Compare Roman v. Sincock, 377 U.S. 695, 710-11 (1965).

79 See Germano v. Kerner, 241 F. Supp. 715, 721 (N.D. I11.), vacated and remanded per curiam sub nom. Scott v. Germano, 381 U.S. 407 (1965); WMCA, Inc. v. Lomenzo, 238 F. Supp. 916, 921-22 (S.D.N.Y.), aff'd per curiam, 86 Sup. Ct. 24 (1965) ; Forty-Fourth Gen. Assembly v. Lucas, 379 U..S. 693 (1965) (semble).

80 In WMCA, Inc. v. Lomenzo, supra note 79, plaintiffs made numerous attacks under the state constitution on the newly passed reapportionment act, although they made no claim that the act was invalid because it enlarged the membership of the assembly beyond that permissible under the state constitution. Id. at $920,921 \mathrm{n} .1$. The district court stated, however, that all the provisions of article III of the New York Constitution which related to apportionment remained in effect except to the extent that they were in unavoidable conflict with federal reapportionment standards. The court added that if these provisions were to fall because "inseparably intertwined with the 'constitutional formulas' condemned by the Supreme Court," it would be by consequence of state rather than federal law. Id. at 921. The court declined to pass upon claims under the state constitution, noting that there was a complementary proceeding pending in the state court. Id. at 922. The state courts found that the provision regulating the maximum size of the assembly was separable and thus acted to invalidate the reapportionment act. In re Orans, 45 Misc. $2 \mathrm{~d} 616,257$ N.Y.S.2d 839 (Sup. Ct.), aff'd, 15 N.Y.2d 339, 206 N.E.2d 854, 258 N.Y.S.2d 825 (1965), appeal dismissed per curiam sub nom. Rockefeller v. Orans, 86 Sup. Ct. 75 (1965)' Uitimately, the 1965 election was held under the act in violation of the state constitution. See text accompanying notes 99-100 infra.

In Pennsylvania, the roles of the federal and state courts were inverted. The district court discerned no ambiguity and declared inoperative certain provisions of the state constitution. Drew v. Scranton, 229 F. Supp. 310 (M.D. Pa. 1964). The Pennsylvania Supreme Court, however, subsequently saved the same provisions by construing them in accord with the federal reapportionment cases. Butcher v. Bloom. $415 \mathrm{~Pa}$. 438, 203 A.2d 556 (1964). The state court was rewarded by being given control of the reapportionment process. Scranton v. Drew, 379 U.S. 40 (1964) (semble). See text at notes 109-16 infra.

81234 F. Supp. 191 (D. Vt. 1964), aff'd with modification stib nom. Parsons v. Buckley, 379 U.S. 359 (1965). 
reapportionment relief would have been postponed for five and one-half years. The court avoided this result under the supremacy clause by finding that the "time lock" provisions could not "restrain this Court from ordering that the Vermont General Assembly be reapportioned or restrain action by officers of the State to set in motion machinery to do so by any other means that would not be discriminatory under the Federal Constitution." 82

The practice of giving time force under the supremacy clause has direct precedent in the desegregation decisions' requirement of "all deliberate speed." 83 Time derives its importance from the declaration of a right, for the delayed implementation of a right is a pro tanto wrong. In the reapportionment area, moreover, the quotidian theory ${ }^{84}$ of the wrong places special emphasis on time, and to the extent that the focus on time flows directly from the right to an undiluted vote, it has constitutional force.

The decision in Schaefer $v$. Thomson ${ }^{85}$ is at the other extreme from Buckley. The court there found that the Wyoming Senate was malapportioned, but withheld affirmative relief until the legislature had an opportunity to act. The Wyoming Constitution provided that each county should constitute an election district and have at least one senator and one representative in the legislature, but the number of representatives was not to be less than three times the number of senators. The court found that while these provisions could theoretically be satisfied, the legislature created thereby would be very large. On the other hand, the court decided that the history of the state evinced an intention that the legislature of Wyoming remain small. The court therefore announced that if it were required to undertake the reapportionment of the Wyoming Senate, it would do so "without regard to the Wyoming constitutional provisions insofar as they relate to the members of the senate . . . . So far as this Court is concerned, the Wyoming legislature may proceed likewise." 88 In an attempt to justify its position, the court stated that none of the reapportionment cases "require[s] that a federal court adhere blindly to state law when to do so would produce a ridiculous result or perpetrate a manifest injustice upon a state and its people." 87 This is a curious statement, proceeding upon the mistaken theory that a federal court's power in the reapportionment sphere is plenary except as limited by recent decisions. To the contrary, where there is no direct or implied conflict with either the substantive or temporal requirements of the right to an undiluted vote, the

82 Id. at 198; see Roman v. Sincock, 377 U.S. 695, 710-11 (1965).

83 Brown v. Board of Educ., 349 U.S. 294, 300-01 (1954) ; Bush v. Orleans Parish School Bd., 205 F. Supp. 893, 898 (E.D. La.), modified, 308 F.2d 491 (5th Cir. 1962).

84 See note 42 sipra and accompanying text.

85240 F. Supp. 247 (D. Wyo. 1964).

86 Id. at 253.

87 Id. at 253 n.9. 
federal court has no power to disregard state constitutional provisions. ${ }^{88}$ In Schaefer, since the problem was ultimately a severability question, the courts of Wyoming were the proper bodies to resolve it. Furthermore, it was extreme to characterize a larger than usual legislature as a "ridiculous result" ${ }^{89}$ when it is in fact merely an historically unusual result; of course, if it is an unintended result it need remain so only for a short time while the state makes the adjustments necessary to normalize the situation. If the result is undesirable, the remedy lies in the hands of a cognizant party who can litigate the issue in a state court-during which time the federal court may stay its order-and not in federal court vitiation of valid state constitutional provisions.

Lying squarely between the Vermont and Wyoming cases is the recent clash of state and federal equity powers in the state of New York. In June 1964, the Supreme Court invalidated the apportionment provisions of the New York Constitution..$^{90}$ The district court then ordered that the 1964 general election be held under the invalidated system, but limited terms of office to one year..$^{91}$ In that election, Republican majorities in both houses were wiped out because of the overwhelming defeat of the Republican presidential candidate. The "lameduck" Republican legislature ${ }^{82}$ then passed four strongly gerrymandered reapportionment plans, each of which provided for a general assembly larger than the 150 member body permitted by the New York Constitution. ${ }^{93}$ The first of these plans ("Plan A") was approved by the district court. ${ }^{94}$ On April 15, 1965, the Court of Appeals of New York held that the 150 member limitation was separable from the invalidated apportionment provisions and that "Plan A" therefore violated the New York Constitution. ${ }^{95}$ Nevertheless, the district court ordered a special election to be held under "Plan A" in

88 Reynolds v. Sims, 377 U.S. 533, 584 (1964).

89 The genuinely "ridiculous" result is more difficult. In Herweg v. Thirty Ninth Legislative Assembly, 246 F. Supp. 454 (D. Mont. 1965), adherence to a constitutional provision that "in no case shall a senatorial district consist of more than one county" would have required a senate membership of approximately 754. Id. at 461 . The court voided this provision of the section which was otherwise void. This latter fact makes it easier to find that the provision quoted was an inseparable part of the void constitutional plan, and the large number of senators required if the federal standards were also to be satisfied strengthens this conclusion. If in less extreme situations uncertainty remains, the proper approach may be to grant a stay of the order until the problem is resolved by state courts. If this course entails a high probability of delay, there is no other choice but to void the provision unless without doing so a "workable" plan could be formulated.

90 WMCA, Inc. v. Lomenzo, 377 U.S. 633 (1964).

21 WMCA, Inc. v. Lomenzo (S.D.N.Y., July 27, 1964), in N.Y. Times, July 28, 1964, p. 1, col. 1, aff'd sub nom. Hughes v. WMCA, Inc., 379 U.S. 694 (1965).

92 The legislature was called into extraordinary session by the Republican governor. It was reported that in response to criticism the governor replied either "I don't care if the Democrats don't like it . ." or "If the Democrats were in my position, they would do the same thing." Asch, supra note 55, at 203.

93 Reapportionment Compliance Act of 1964, N.Y. Unconsol. Laws §§ 2361-64, 2371-73, 2381-83, 2391-93 (McKinney Supp. 1965).

94 WMCA, Inc. v. Lomenzo, 238 F. Supp. 916 (S.D.N.Y. 1965).

95 In re Orans, 15 N.Y.2d 339, 206 N.E.2d 854, 258 N.Y.S.2d 825 (1965). 
November, $1965 .{ }^{\circ 6}$ With the head on clash clearly defined, relief was sought from the Supreme Court in the form of an acceleration of appeal or a stay of the order until the appeal was heard. In Travia $v$. Lomenzo ${ }^{87}$ the Court denied these motions per curiam with Mr. Justice Harlan dissenting. The courts of New York then enjoined compliance with the district court's order ${ }^{98}$ in turn, the district court issued a permanent injunction barring any interference with the special election. ${ }^{99}$ Finally, on July 16, 1965, Mr. Justice Harlan issued a memorandum in his capacity as Circuit Justice refusing applications for a stay of the election. ${ }^{100} \mathrm{He}$ based this action on the grounds that the Supreme Court had indicated its unwillingness in Travia $v$. Lomenzo to interfere with the district court's order and that the supremacy clause therefore required recognition of that order. Mr. Justice Harlan went on to observe that the New York courts should have fashioned appropriate relief after the district court's order, and that the federal courts might have accepted alteration of the existing plan "on considerations of comity inherent in federalism." Nevertheless, he concluded that it was too late to expect that a staying of the order would lead to the formulation of an acceptable plan.

The validity of the 150 member limitation must be granted for several reasons: (1) it had been approved by the New York courts, ${ }^{101}$ and their power to rule on the issue had been accepted by the district court; ${ }^{102}$ (2) there was no suggestion that the reapportionment of the state could not take place if this requirement were recognized; (3) there is nothing in federal law which implies that a state constitution cannot limit membership in a state legislative body to 150 members. The initial decision of the district court is thus no more justifiable than that of the district court in Schaefer $v$. Thomson. After receiving authoritative determination of the invalidity of "Plan A" under state law, the district court should have ruled that no acceptable plan had been presented by the legislature and should then have fashioned its own relief, paying heed to the 150 member provision. If the court had not set up machinery to aid it in fashioning relief, however, its decision might possibly be supported on the ground that accommodation of the numerical membership requirement in the circumstances of this case would have impermissibly interfered with the temporal requirements of implementing the remedy. In other words, having determined that the remedy must be implemented by November 1965, there was no other practical way to reapportion the state in the five month interim before the election. To this extent, the New York resolution differs from the Wyoming case, in which the suggestion that valid state provisions

96 The order was issued on May 10, 1965. N.Y. Times, May 11, 1965, p. 1, col. 6. 87381 U.S. 431 (1965).

08 Glinski v. Lomenzo, in N.Y. Times, July 10,1965, p. 1, col. 8.

89 N.Y. Times, July 14, 1965, p. 26 , col. 2 .

100 Reported in N.Y. Times, July 17, 1965, p. 9, col. 1.

101 See In re Orans, 15 N.Y.2d 339, 206 N.E.2d 854, 258 N.Y.S.2d 825 (1965).

102 See note 80 supra. 
could be ignored was given before the legislature had an opportunity to act and while substantial time remained for the formulation of the reapportionment plan. In the New York litigation, however, there was no suggestion that the court itself could not come forward with a valid apportionment plan or adopt one of the suggested alternatives (or a variation thereof) presented by the parties to the suit. ${ }^{103}$ Unless these alternatives are excluded, the imposition of a legislature sitting in violation of the state constitution was error, and the affirmance of this act by the Supreme Court ${ }^{104}$ may be viewed as a forced choice between continuing the wrong of malapportionment because of the district court's error in not providing for alternatives in case of legislative default, and correcting that wrong at the expense of roughshod treatment of the state's constitution.

\section{The Curtailment of District Court Remedial Power by State Court Intervention ${ }^{105}$}

If the state legislature is found to be unqualified to perform the task of reapportionment, the view that such task is a state responsibility suggests that the state court is an appropriate agency in which to vest power to act. As with the issue of federal judicial deference to the state legislature, the broad question of whether the responsibility for management of the remedial process should be allocated to the state courts in preference to the federal district courts turns on equitable considerations. ${ }^{106}$ The case

103 See Brief for Appellants, p. 4, Travia v. Lomenzo, 381 U.S. 431 (1965):

For example, the District Court could have adopted the position of District Judge Richard $\mathrm{H}$. Levet, who dissented from the May 24 order, that the 1966 Legislature be elected in 1965 along existing legislative lines and that weighted voting be adopted in the 1966 Legislature . . ; it could have granted the motion of appellants to continue the present Legislature in office until December 31, 1966 as provided by the State Constitution (Article III, $\$ 2$ ), and to require weighted voting during the 1966 Legislative session so as to comply with the Federal Constitution; it could have appointed a master to prepare a fully constitutional apportionment plan as requested by plaintiffsappellees ...; it could have required an at large election as suggested by Judge Burke of the New York Court of Appeals in Glinsky v. Lomenzo . . . .

The New York Times editoralized: "But how much better off the State of New York might be today if the court had granted the motion of counsel for radio station WMCA, the original plaintiff . . . and appointed a special master last March to prepare a nonpartisan apportionment plan for use in the event the Legislature failed to act." N.Y. Times, July 14, 1965, p. 36, col. 2.

104 WMCA, Inc. v. Lomenzo, 86 Sup. Ct. 24 (1965) (per curiam).

105 The previous section dealt with the advisability or necessity of district court abstention from decision of particular issues of state law in the specific context of reapportionment litigation. The present section is concerned with the application of the abstention doctrine on a broader scale: abstention from management of the remedial process. In the New York litigation, for example, the state court did not purport to assume the remedial process; in fact its attitude was totally negative. In re Orans, 15 N.Y.2d 339, 206 N.E.2d 854, 258 N.Y.S.2d 825, appeal dismissed sub nom. Rockefeller v. Orans, 86 Sup. Ct. 75 (1965). In this section the problem is posed by the assumption by state courts of more than a fragment of the case, and this necessitates a comparison of the federal and state courts in terms of relative suitability for management.

106 A federal court clearly has power to decide the case, Butterworth v. Dempsey, 229 F. Supp. 754, 792-93 (D. Conn.) (memorandum on form of judgment), aff'd 
for management of the reapportionment process by the state judiciary is substantially stronger than that for the state legislature: its legitimacy is not affected by a finding of malapportionment, and it does not possess the same degree of self interest in the apportionment process. Indeed, the Supreme Court has held that a state court reapportionment decision which indicates that the state court is willing to undertake supervision of the remedial process is sufficient to displace concurrent action by a federal district court. ${ }^{107}$ This will be so even where the federal court was the first to receive the case, has made a final judgment on the merits, and has already begun to outline the remedial process. ${ }^{108}$

Although the Supreme Court had given indications that it would prefer the state courts to assume the remedial role in reapportionment, ${ }^{109}$ the fact that state court intervention would force federal court abstention did not become clear until the apportionment litigation in Pennsylvania. A district court in that state had ordered in April, 1964 that the 1964 general election be held under an acceptable plan passed by the state legislature or, upon its default, under a court made plan, but the court stayed its order pending appeal to the Supreme Court. ${ }^{110}$ In September the Supreme Court of Pennsylvania handed down a decision ${ }^{111}$ saving certain apportionment provisions of the state constitution by construction, ${ }^{112}$ but concurring with the district court that the apportionment legislation of the state was unconsitutional. The Pennsylvania court found, however, that the legislature could not act properly in time for the 1964 elections and since it concluded that the legislature would be "more likely to achieve a workable, constitutionally acceptable result than an apportionment following the suggested plan of the district court," 113 the court ordered that the 1964 election be held under the invalidated apportionment acts and directed the legislature to come forward with an acceptable apportionment scheme to be employed in the 1966 general election by September 1, 1965. The court indicated that legislative default would lead it to take the "necessary affirmative action" to insure constitutional apportionment in 1966.114 On appeal from the district court decision, the Supreme Court noted in Scranton v. Drew ${ }^{115}$

per curiann sub noni. Pinney v. Butterworth, 378 U.S. 564 (1964). Abstention considerations are equitable in nature, though with constitutional overtones. See Friedelbaum, Baker v. Carr: The New Doctrine of Judicial Intervention and Its Implications for American Federalism, 29 U. CHI. L. REv. 673, 701-02 (1962). See generally Wright, Federal Courts 169-77 (1963) ; Note, 108 U. PA. L. Rev. 226 (1959). 107 Scott v. Germano, 381 U.S. 407 (1965), vacating and remanding per curiam Germano v. Kerner, 241 F. Supp. 715 (N.D. III. 1965). 108 See Germano v. Kerner, supra note 107, at 719. (1964). 109 See Maryland Comm. for Fair Representation v. Tawes, 377 U.S. 656, 674 110 Drew v. Scranton, 229 F. Supp. 310 (M.D. Pa.), vacated and remanded per curiam, 379 U.S. 40 (1964). 11iButcher v. Bloom, 415 Pa. 438, 203 A.2d 556 (1964). 112 See note 80 supra. $113415 \mathrm{~Pa}$. at $447,203 \mathrm{~A} .2 \mathrm{~d}$ at 561. 114 Id. at 468,203 A.2d at 573. 115379 U.S. 40 (1964). 
that the district court's decision antedated Reynolds $v$. Sims and its companion cases, quoted excerpts from the Pennsylvania Supreme Court's decision showing that court's intention to act, and vacated the judgment of the district court, remanding the cause "in light of the decisions supervening since the entry of the judgment of the District Court." This last quoted clause, phrased in the plural, was taken by both the district and state courts to include the decision of the Pennsylvania Supreme Court, for the remedial process was thereafter left with the Supreme Court of Pennsylvania. 116

All doubt about the meaning of the Pennsylvania litigation was resolved in Scott $v$. Germano. ${ }^{117}$ The district court in that case issued an order restraining the holding of elections under invalidated Illinois constitutional and statutory provisions and requiring that any apportionment scheme passed by the legislature be presented to the court for approval. ${ }^{118}$ The court also ordered the defendants to show cause why the elections of 1966 should not be held at large in the event of legislative default. Taking a narrow view of the decision in Scranton $v$. Drew, ${ }^{119}$ and resisting a statutory attack on the court's power under section 2284(5) of the Judiciary Act, ${ }^{120}$ the district court held that the decision of the Illinois Supreme Court in People ex rel. Engle v. Kerner ${ }^{121}$ (a decision which postdated the district court order and which concurred with the district court in the invalidation of the apportionment of the state senate) did not require the

116 After the remand, the senate and the house passed acts reapportioning their respective chambers on August 26 and 27,1965 . The governor called the house bill "the result of machine politics at its worst . . . The whole purpose of it is to insure 10-year rule of the House by the Democratic City Committee of Philadelphia." The Philadelphia Evening Bulletin, Aug. 27, 1965, p. 1, col. 8. The two houses were unable to agree on a combined plan and failed to meet the September 1 deadline imposed one year before by the Pennsylvania Supreme Court in Butcher v. Bloom, $415 \mathrm{~Pa} .438,203$ A.2d 556 (1964). The deadline was extended to September 9, while the dispute focused upon redistricting of the house, "where Republicans are insisting upon a plan that would improve their chances of regaining control." N.Y. Times, Sept. 5, 1965, p. 49, col. 5. After the legislature breached a second extension of the deadline (October 18), the Pennsylvania Supreme Court took over redistricting with nine plans before it submitted by the parties and interested civic groups. N.Y. Times, Oct. 21,1965 , p. 5 , col. 6 .

On February 4, 1966, the Pennsylvania Supreme Court handed down a per curiam decision apportioning both houses of the legislature. Justices Eagen and Musmanno dissented, and Justice Roberts dissented in part. Chief Justice Bell disagreed with certain aspects of the decision, as he regretted that the plan required some senators to contest their seats three times in four years. Justice Musmanno dissented because of the creation of an extra house seat in Bucks County. The Philadelphia Inquirer, Feb. 5, 1966, p. 1, col. 1; p. 3, col. 5. Although at the time of this writing the political implications of the redistricting were not clear, the Committee of Seventy, a civic group which had initiated the Pennsylvania reapportionment litigation, charged that the plan raised serious constitutional questions and was undertaking a study to determine whether to contest implementation. Philadelphia Sunday Bulletin, Feb. 6, 1966, $\S 1$, p. 6 , col. 1 .

117381 U.S. 407 (1965).

118 Germano v. Kerner (N.D. I11. Jan. 22, 1965), reported in Germano v. Kerner,

241 F. Supp. 715, 717 (N.D. I11. 1965).

119 Germano v. Kerner, 241 F. Supp. 715, 721 (N.D. I11. 1965).

12028 U.S.C. $\$ 2284(5)$ (1964).

12132 I11. 2 d 212, 205 N.E.2d 33 (1965). 
district court to stay its hand or to vacate its judgment. ${ }^{122}$ The Supreme Court vacated and directed the contrary disposition, stating that the power of a state judiciary to manage the apportionment process had not only been recognized, but had been "specifically encouraged," 123 citing inter alia Scranton $v$. Drew. The case was remanded with directions that the district court set a reasonable time within which the "appropriate agencies of the State . . . including its Supreme Court, may validly redistrict the . . . Senate; provided that the same be accomplished within ample time to permit such plan to be utilized in the 1966 election. . . ." 124 On default of the state agencies, the district court was authorized to issue its own plan or to order an election at large.

The abstention doctrine was injected into Scott $v$. Germano only after the state court had expressly indicated its willingness to undertake the remedial process ${ }^{125}$ and after a federal court had determined the substantive issues in the case; federal court power was thus limited solely in the remedial area. Moreover, even this limitation was incomplete ${ }^{126}$ since the federal court was permitted to retain control of the crucial time factor. ${ }^{127}$ Granting these limitations, it is still not clear that the order to abstain is supportable. While the only express grounds for the order were merely that the state courts had power to act in this area and that the Supreme Court had encouraged the exercise of this power, the probable motivation was the standard assuaging ground of comity-minimal interference in state policy making and processes. ${ }^{128}$ Although this goal has obvious appeal, it is not clear that it could be served to a significant degree in this case.

First, the mere finding of malapportionment goes so deeply into the heart of the state political process that requiring the federal court to make a premature exit from the remedial process, while it may serve placating

122 Germano v. Kerner, 241 F. Supp. 715, 722 (N.D. I11. 1965).

123 Scott v. Germano, 381 U.S. 407, 409 (1965).

$124 \mathrm{Id}$. at 409-10. On remand, the legislature adjourned without enacting apportionment legislation, and the district court, rather than abstaining, joined with the state court in the formulation of a reapportionment plan for the state senate. See note 126 infra.

125 People ex rel. Engle v. Kerner, 32 I1l. 2d 212, 237, 205 N.E.2d 33, $40-41$ (1965).

126 In fact, the district court did not "abstain." After Scott v. Germano, 381 U.S. 407, decided on June 1, 1965, the district court set September 10,1965 as a deadline (later extended to October 4) for reapportionment. On June 30, the Inlinois General Assembly adjourned without redistricting. On July 30, the Supreme Court of Illinois ordered the parties to confer for the purpose of formulating a plan. Thereafter, the district court by Judge Cambell "with the knowledge and approval of the Supreme Court of Illinois, conducted numerous and extensive pretrial conferences ..." Germano v. Kerner, 247 F. Supp. 141, 143 (N.D. I11. 1965). When the parties were unable to agree, the district court and the Illinois court joined in formulating a plan which counsel for the parties had agreed to accept. The plan was approved by each court in Germano v. Kerner, supra, and People ex rel. Engle v. Kerner, 210 N.E.2d 165 (Ill. 1965), where the above facts are reported. The same unconventional approach to cooperative federalism may be followed for the reapportionment of the Illinois house. See N.Y. Times, Oct. 17, 1965, p. 29, col. 1 .

127381 U.S. 407, 409 (1965).

128 See Wright, Federal Courts 169, 173-74 (1963). 
purposes, will yield few utilitarian advantages. If the state court intends to defer to the state legislature, its influence on plan formulation is accordingly reduced and its position is no better than that of the federal court, unless one engages in the questionable speculation that the state court can better prod the legislature than the federal court can. If, on the other hand, the state court intends to formulate a plan of its own, either initially or in the case of legislative default, one can argue vaguely that a more "state like" plan will result. It is questionable, however, whether the state court, with its inexperience in these matters, can make sufficiently sophisticated use of the limited options available in a short period of time to justify viewing its formulation as representing a state policy, except in the shallow sense that the decisions are being made by a state agency. This doubt is reinforced by the probability that the state court will have to rely upon the same type of expert advice that would be available to the federal court. Instead it seems clear that a "state policy" on apportionment will not be available until established by the first legislature of the state to be elected under a constitutional apportionment scheme.

Moreover, the proximity to "local" problems which constitutes the purported strength of the state courts may actually militate against them in the selection of the optimum agency for the management of reapportionment. The selection process for state judges favors those who have been active in partisan politics and who may be in political debt. ${ }^{129}$ Even if the existence of political ties in this area of high partisan spoils would not affect the objectivity ${ }^{130}$ of a judge in carving out new election districts, the fact is that state legislators may think otherwise, and the reapportionment process may be delayed or distorted in reliance on such beliefs. One party may refuse to make concessions if its members believe that the state court will formulate a plan favorable to them in the event of a legislative stalemate. ${ }^{131}$

To make a judgment that the same problems will not befall the federal district courts is not to overlook the fact that many of the district

129 See Kaufman, Polrtics and Policies in State and Local Governments 59 (1963) ; Lockard, The Politics of State and Locai Government 457-59 (1963); Mayers, The American Ifegal System 385-86 (1964); Sayre \& Kaufman, GovERNING NEW YORK CITY 522-54 (1960).

130 But see Nagel, Political Party Affiliation and Judges' Decisions, 55 Ans. PoL. Scr. REv. 843, 850 (1961), suggesting that there is a party correlated subjectivity in judicial decision making, at least in areas of party oriented value preferences.

131 On remand of the Illinois and Pennsylvania cases, concern over the state courts' partisan leanings became manifest. In Pennsylvania, one Democrat charged that the governor was "throwing his weight around" to see that no reapportionment plan would be passed so that the reapportionment would be done by the Pennsylvania Supreme Court to Republican advantage. The Philadelphia Evening Bulletin, Aug. 27,1965 , p. 1, col. 8. In Illinois the granting of reapportionment management to the partisanly elected and Republican controlled supreme court was viewed as a Republican victory. See 54 NAT'L CrvIC REv. 372 (1965). Neither legislature was able to agree on a reapportionment plan, and both failed to meet their deadlines. See notes 116,126 supra. 
court judges have partisan backgrounds. ${ }^{132}$ Such a judgment would instead go beyond this fact and focus on the following considerations: that federal judicial appointments are in fact of national origin; that the three judge district court array has a very strong national orientation, and that the federal court judges are firmly insulated from the tides of state partisan politics. ${ }^{133}$ In particular, federal judges would be less "accessible" in the eyes of the state legislators.

Despite these considerations, there are other grounds upon which the Germano decision may be supported. To begin with, the decision saves the federal courts a great deal of time, ${ }^{134}$ and there will be no question of casting an unsolicited burden upon the state court system when, as in Germano, the state court indicates its willingness to undertake the remedial process. ${ }^{135}$ In addition, the Germano approach helps to insulate the federal courts from the heat of political criticism. Finally, it is noteworthy that the Supreme Court decided Germano on the same day that it decided Travia $v$. Lomenzo, the case which insured that the apportionment of $\mathrm{New}$ York would proceed in violation of the New York Constitution. ${ }^{136}$ Germano may be viewed as the product of Travia, for the Supreme Court may well have been seeking to eradicate the problems faced in the unseemly New York litigation. The move may be well taken to the extent that the problems in New York were the result of a lack of rapport between the federal and state court systems. On the other hand, while it is laudable to avoid a conflict between state and federal powers, such a course should not be followed if it delays or dilutes the remedy to be afforded the voters of a malapportioned state. Even where a problem similar to that of New York arises-that is, where the state is reapportioned under a plan which is in derogation of intrinsically valid provisions of a state constitution, or where there remain problems which a federal court does not clearly have the power to resolve in reapportioning-preservation of the integrity of the remedy should be the controlling consideration, for at the very least there will be a reconstructed "representative" legislature available to make modifications to resolve the conflicts between federal and state requirements. Such a choice between federal time and substantive demands and state substantive demands occurs only where there is a feeling that state and federal requirements cannot both be satisfied in time for an early apportionment, and it is necessary to decide which requirements must be given priority. It is submitted that the supremacy clause requires that priority

132 See Mott, Albright \& Semmerling, Judicial Personnel, in Judictal Beravior 195, 201 (Schubert ed. 1964). (The essay, written in 1933, may be outdated.)

133 See Note, 72 Yale L.J. 1646, 1652-53 (1963); cf. Mishkin, The Federal "Question" in the District Courts, 53 Colum. L. REv. 157, 158 (1953). Professor Mishkin's stress on the value of a federal court as initial factfinder where review of facts is difficult is also pertinent here. See $i d$. at 171 .

134 See Wriget, Federal Courts 176-77 (1963); note 51 supra.

135 See People ex rel. Engle v. Kerner, 32 I1l. 2d 212, 205 N.E.2d 33 (1965).

136 See text accompanying notes 97-100 supra. 
be given to federal requirements, and that since the federal court would be more disposed to afford such priority, that it should remain in control of the apportionment process.

\section{Conclusion: A Remedied Remedy}

That the Supreme Court's reapportionment opinions lack any consideration of the implications of the declaration of the right to an undiluted vote for the implementation of the remedy and of the probable consequences of entrusting the process to partisan bodies suggests that the Court's directives were not grounded on constitutional or equitable considerations, but were rather an attempt to mollify the state legislatures for the invasion of their preserve. The deficiency in the Court's approach was the unrealistic concentration on the proper allocation of responsibility had malapportionment neither been extant nor a constitutional wrong. It is pointless to assert that a matter is ordinarily the responsibility of a particular state agency when the real question is whether those very agencies have been incapacitated by remedy diluting political ties and self-serving preoccupations.

A remedial procedure consonant with the analysis in this Comment would proceed along the following lines:

Upon finding malapportionment a district court should appoint a special master competent to prepare a nonpartisan redistricting plan ${ }^{137}$ based upon the functional criteria of equal population, compactness and contiguity of districts. ${ }^{138}$ Upon receipt of a plan or plans so prepared, the court should

137 See, e.g., Stout v. Bottorff, 246 F. Supp. 825 (S.D. Ind. 1965) (appointment of panel consisting of the deans of three law schools to prepare a standby plan); Butterworth v. Dempsey, 237 F. Supp. 302 (D. Conn. 1965) (appointment of the Director of the Yale Computer Research Center as special master).

Professor McKay has suggested that to insulate the reapportionment process from the "seriously distorting effects of partisan politics," it should be left to nonpartisan apportionment commissions at the state level. He suggests guidelines for the organization and operation of such commissions. MCKAY, REAPPORTIONMENT 269-71 (1965). The same guidelines might be used by the courts in the appointment of reapportionment masters.

138 See Nagel, Simplified Bipartisan Computer Redistricting, 17 STAN. L. Rev. 863 (1965) ; Weaver \& Hess, A Procedure for Non-Partisan Districting: Development of Computer Techniques, 73 YALE L.J. 288 (1963).

Computer redistricting will probably not eliminate the necessity of choosing between districting configurations of different political consequences, for it is likely that a machine programmed for optimum satisfaction of functional requirements and equal population will produce several apportionment schemes. The key point is that the computer method insures satisfaction of the constitutional and functional standards first, and although it leaves political options, it preempts political distortion. When alternative plans are presented, there will undoubtedly be strong pressure on the court to choose that plan which to the best prediction will favor the largest number of incumbents. There would appear to be no federal prohibition of this course, and it may serve to ease transition by contributing to the number of experienced legislators in the reconstructed legislature. It is arguable, however, that there is no reason to favor those individuals who have built up political strength in units distorted by an unconstitutional apportionment scheme. If this is so, it may be wise to take a neutral course by choosing a plan which by prediction will return neither a maximum nor minimum number of incumbents. Another approach would be to choose that plan which predictably will tend to favor a political complexion most nearly approximating 
submit the same to the litigants and to the state legislature (for the benefit of their experience) for suggestions of such alterations as may be permissible because they are "based on legitimate considerations incident to the effectuation of a rational state policy." Such an approach would preserve the "controlling" principle of equal population, while providing for permissible deviations from mathematical equality. Most importantly, it would indicate to the court precisely where the variances are and focus attention on the justifiability of each variance. When this formulation process has been completed, the court should schedule speedy implementation whether or not an election would ordinarily be held in that year, but with regard to the mechanics and time provisions of the state regulating the nominating, primary and election processes, choosing the most rapid routes where alternative methods are available under state law. These provisions represent judgments as to how long is required for the political parties and voters of a state to deliberate properly on the selection of their representatives, and such judgments ought to be respected, unless so dilatory as to conflict with the district court's judgment as to the allowable time for the implementation of the remedy.

If there should be a strong compulsion to defer either to the state legislature or to the state court, such action should be taken only where there is good reason to believe that the remedial process will not be impeded by incapacitating characteristics of the state agency. In this regard, a court may note that if the legislature is disproportionately one-partied, speedy action is likely, but the danger of gerrymandering is great. Where one party controls only one of two houses, great delay may be expected because partisan considerations will inhibit agreement on a single plan, unless each party decides to sacrifice the house in the opposing party's control. The simplest case is that where no party has disproportionate dominance in either house, and the danger of disguised gerrymandering is consequently reduced. Even in this case, delay is to be expected, but a strictly enforced deadline may solve the problem, and little time will be lost if the court has armed itself with alternatives for use in case of legislative default. In any case where a court decides to defer, its first step should be to provide for a nonpartisan functional plan so that it may have a standard by which to measure any state proposal.

the statewide partisan balance, measured by voter registration-a kind of nondistorting gerrymandering. The difficulty with this approach is that any overtly partisan choice by the court, however justifiable, will undoubtedly expose the court to severe attack.

Although the choice between alternative political results is clearly a state function in ordinary circumstances, criticism of judicial resolution of such problems must take into account the fact that any decision can be modified by the reconstructed legislature. Furthermore, the uncertainty of electorate behavior from election to election does much to counter the assumption that the new legislature will be of a complexion so similar to that predicted at the time that the court made its choice that it will automatically reapportion itself in a manner mirroring the court's original choice. Finally, whatever standard the court uses if forced to choose between alternative plans should be announced well in advance of receipt of the plans by the court to prevent charges of favoritism. 